\title{
SEDIMENTASI DI PANTAI SANTOLO WILAYAH PESISIR SELATAN JAWA BARAT DAN MODEL PENANGGULANGANNYA
}

\section{SEDIMENTATION IN SANTOLO BEACH OF SOUTHERN WEST JAVA COASTAL REGION AND ITS COUNTERMEASURES MODELING}

\author{
Fitri Suciaty \& Ari Setiawan \\ Program Studi Teknik Sipil Institut Teknologi Nasional Bandung \\ J1. PH.H. Mustofa No.2, (022)7272215, Fax (022)7202892 \\ e-mail : fitrisuciaty@itenas.ac.id \\ Diterima tanggal: 17 Februari 2021 ; diterima setelah perbaikan: 7 Juni 2021 ; Disetujui tanggal: 8 Juni 2021
}

\begin{abstract}
ABSTRAK
Pantai Santolo merupakan daerah pesisir yang terletak di Kecamatan Cikelet, Kabupaten Garut, Jawa Barat. Permasalahan sedimentasi dan pendangkalan pada mulut muara Sungai Cilauteureun yang berada di kawasan Pantai Santolo membuat ketidaklancaran arus lalu lintas pelayaran dan menyebabkan penurunan jumlah kapal motor yang berlabuh di Pelabuhan Perikanan Cilauteureun. Hal ini berakibat pada kurang optimalnya pemanfaatan sumberdaya perikanan di area tersebut. Jetty sepanjang $185 \mathrm{~m}$ yang telah dibangun pada bagian timur mulut sungai harus dipotong pada akhir tahun 2019 karena sedimentasi telah menyebabkan terbentuknya tombolo yang menutup alur lalu lintas kapal. Pemodelan hidrodinamika 2-dimensi dan pemodelan transpor sedimen dilakukan pada penelitian ini dengan menggunakan software Delft $3 D$ untuk menganalisis faktor-faktor hidrodinamika yang berpengaruh terhadap proses sedimentasi yang terjadi di Pantai Santolo terutama di area muara Sungai Cilauteureun sehingga dapat diketahui penanggulangan yang sesuai untuk permasalahan tersebut. Simulasi pemodelan hidrodinamika dilakukan untuk skenario musim barat dan musim timur, sedangkan pemodelan transpor sedimen dilakukan dengan durasi selama satu tahun. Jetty sepanjang $120 \mathrm{~m}$ di bagian utara Pulau Santolo dan "sand by passing" pada tombolo yang terbentuk di belakang potongan jetty direkomendasikan pada studi ini untuk mengatasi permasalahan yang terjadi.
\end{abstract}

Kata kunci: Sedimentasi, pantai santolo, pesisir selatan jawa barat, pemodelan hidrodinamika, jetty.

\begin{abstract}
Santolo Beach is a coastal area located in Kecamatan Cikelet, Kabupaten Garut, West Java. Sedimentation and silting problems at the mouth of the Cilauteureun River estuary in the Santolo Beach area have made shipping traffic uneventful and have led to a decrease in the number of motorboats anchored in the Cilauteureun Fishing Port. This results in less than optimal use of fishery resources in the area. The $185 \mathrm{~m}$ long jetty that has been built in the eastern part of the river mouth had to be cut by the end of 2019 because sedimentation had caused the formation of tombolo that closed off the boat traffic. 2-dimensional hydrodynamic modeling and sediment transport modeling were carried out in this study using Delft3D software to analyze the hydrodynamic factors that affect the sedimentation process at Santolo Beach, especially in the area of the Cilauteureun River estuary so that appropriate countermeasures can be found for this problem. Hydrodynamic modeling simulations were carried out for the west monsoon and east monsoon scenarios, while sediment transport modeling was carried out with a duration of one year. A 120 m long jetty in the northern part of Santolo Island and "sand by passing" on the tombolo formed behind the jetty cut is recommended in this study to solve the problems.
\end{abstract}

Keywords: Sedimentation, santolo beach, southern west java, hydrodynamic model, jetty. 


\section{PENDAHULUAN}

Pantai Santolo merupakan daerah pesisir yang terletak di Kecamatan Cikelet, Kabupaten Garut, Jawa Barat dan merupakan objek wisata yang menyimpan daya tarik cukup beragam. Di area Pantai Santolo terdapat Pelabuhan Perikanan Cilauteureun yang letaknya berada di bagian muara Sungai Cilauteureun. Pelabuhan Perikanan Cilauteureun merupakan salah satu Pelabuhan Perikanan di Jawa Barat bagian selatan yang memiliki jumlah nelayan paling banyak dibandingkan dengan kecamatan pesisir lainnya di Kabupaten Garut. Data Badan Pusat Statistik Kabupaten Garut pada tahun 2016 menunjukan jumlah nelayan di Kecamatan Cikelet sebanyak 1.166 nelayan dengan hasil produksi perikanan sebesar 1.163 ton pertahun yaitu senilai Rp26.204.730,70 pertahun. Produksi perikanan rata-rata di Kecamatan Cikelet sebesar 5\% dari produksi perikanan di Kabupaten Garut (Jayanti \& Wiyono, 2009). Namun, menurut Dinas Perikanan dan Peternakan Kabupaten Garut, potensi sumberdaya perikanan di Kabupaten Garut untuk ZEE (Zona Ekonomi Ekslusif, 200 mil laut dari garis pantai) memiliki luas area penangkapan sekitar $28.560 \mathrm{~km}^{2}$ dan diestimasi memiliki potensi lestari ikan sekitar 166.667 ton pertahun. Sementara untuk zona teritorial (12 mil laut dari garis pantai) memiliki potensi ikan sebesar 10.000 ton pertahun. Dinas Perikanan dan Kelautan Kabupaten Garut menyatakan hasil produksi perikanan hanya sekitar $49,9 \%$ dari potensi yang ada.
Penggunaan armada tangkap dengan kapasitas dibawah 10 GT menjadi penyebab tidak optimalnya pemanfaatan potensi sumberdaya yang ada. Selain itu, arus lalu lintas pelayaran nelayan di Pelabuhan Perikanan Cilauteureun juga terganggu oleh adanya sedimentasi pada muara Sungai Cilauteureun. Pada saat air laut surut Kapal Motor (KM) tidak bisa berlabuh dan mengakibatkan penurunan jumlah Kapal Motor (KM) (Soedjana, 2002).

Wilayah perairan di Pantai Santolo memiliki tingkat sedimentasi yang cukup tinggi, terutama di bagian muara Sungai Cilauteureun. Berdasarkan penelitian yang dilakukan oleh Pratomo et al (2017), diketahui laju sedimentasi di muara Sungai Cilauteureun yang berada di kawasan Pantai Santolo pada Mei 2016 mencapai $18,0025 \mathrm{gr} / \mathrm{m} 2 /$ hari. Untuk mengatasi permasalahan tersebut dibangun jetty bagian kanan muara sungai. Pembangunan jetty ini telah mengalami beberapa kali perubahan desain dan penambahan panjang dalam dekade ini.

Gambar 1 menunjukan kondisi area studi saat ini, dimana jetty yang telah dibangun sepanjang $185 \mathrm{~m}$ harus dipotong menjadi sepanjang $65 \mathrm{~m}$ dan dibuat alur kapal dengan lebar hanya $15 \mathrm{~m}$ karena adanya tombolo yang menutup alur lalu lintas kapal yang seharusnya berada di ujung jetty. Garis biru adalah garis pantai di belakang struktur pada 2011, garis merah adalah garis pantai pada 2018, sedangkan garis kuning adalah garis pantai pada pertengahan 2019. Pada akhir 2019 terlihat

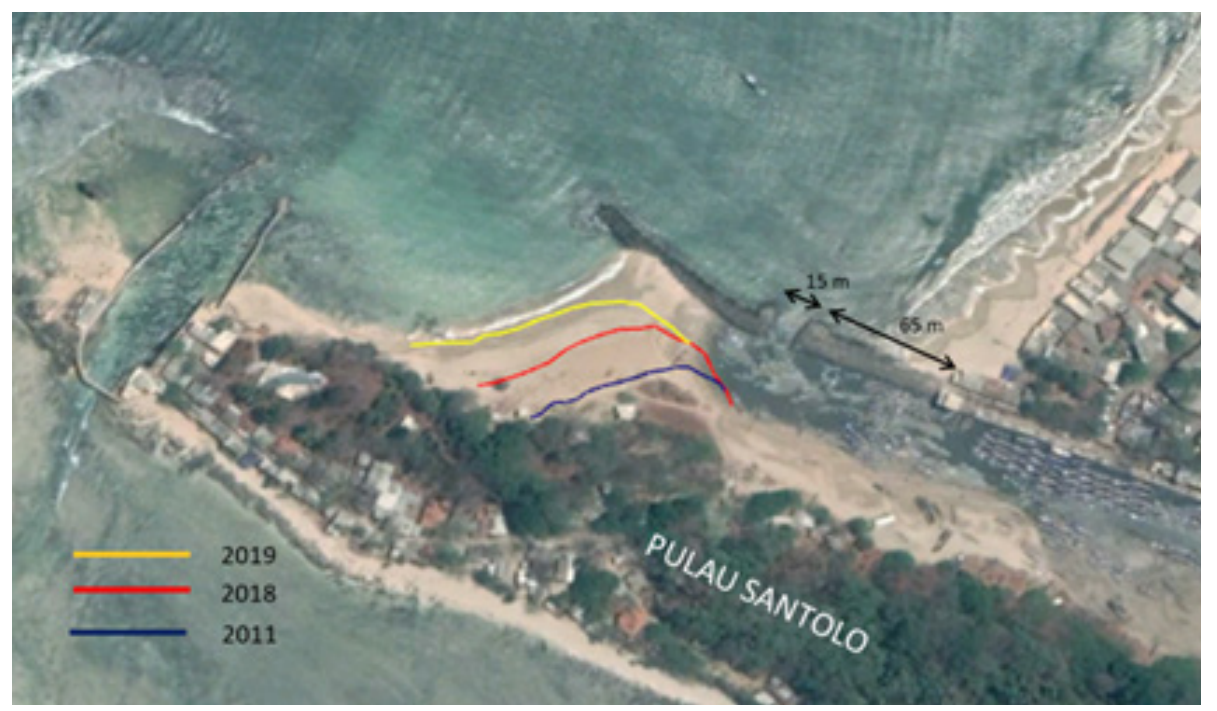

Gambar 1. Kondisi lokasi penelitian dari citra google earth pada November 2019 serta perubahan garis pantai yang terjadi di belakang jetty pada tahun 2011,2018, dan 2019.

Figure 1. The condition of the study area from google earth imagery in November 2019 and shoreline changes behind the jetty in 2011, 2018 and 2019.

Sumber: Hasil penelitian

JURNAL KELAUTAN NASIONAL, Vol. 16, No 1, April 2021, Hal. 65-76 
sedimen sepenuhnya menutup alur kapal.

Pada studi ini, pemodelan hidrodinamika 2-dimensi dan pemodelan transpor sedimen, menggunakan Delft3D (Deltares, 2004), dilakukan dengan tujuan untuk mengetahui faktor-faktor hidrodinamika yang berpengaruh terhadap sedimentasi yang terjadi (Prihantono, et al. 2018). Selanjutnya hasil analisis pemodelan digunakan sebagai dasar dalam menentukan rekomendasi perencanaan yang sesuai dan efektif untuk menanggulangi permasalahan tersebut (Rachman et al., 2013; Prihantono et al., 2018; Purbani et al., 2019).

\section{BAHAN DAN METODE}

\section{Pemodelan Hidrodinamika dan Transpor Sedimen}

Pemodelan hidrodinamika 2-dimensi pada penelitian ini dilakukan dengan menggunakan Delftd3D versi open source software. Sistem pemodelan Delft3D dirancang untuk dapat mensimulasikan perambatan gelombang, arus, transpor sedimen, perubahan morfologi dan juga kualitas air di daerah pesisir, sungai dan muara sungai. Model yang digunakan yaitu Delft3D-Flow dan Delft3D-Wave.

Model Flow pada Delft3D yaitu pemodelan hidrodinamika yang mensimulasikan program untuk menghitung fenomena aliran yang dinamis karena pasang surut dan meteorologis. Persamaan pengatur model hidrodinamika 2D di dalam flow model diatur berdasarkan persamaan kontinuitas dan momentum di dalam sumbu $-\mathrm{x}$ dan $-\mathrm{y}$ berturut-turut di dalam grid curvilinier.

Delft3D-Wave adalah sistem bagian dari Delft3D yang berfungsi untuk mensimulasikan perambatan gelombang yang dihasilkan di perairan pantai dan juga dapat diterapkan di perairan dalam, menengah dan dangkal (Fahmi \& Hafli, 2019). Persamaan yang mengatur model Delft3D-WAVE adalah persamaan kesetimbangan spektrum gelombang. Berikut adalah persamaan pembangun yang digunakan di dalam Program Delft-3D.

Persamaan Momentum dalam Arah Horisontal

$$
\begin{gathered}
\frac{\partial \zeta}{\partial r}+\frac{u \partial u}{\sqrt{G \zeta \zeta} \partial \zeta}+\frac{v \partial u}{\partial \eta \sqrt{G \eta}}+\frac{\omega \partial u}{d+\zeta \partial \sigma} \\
-\frac{V^{2} \sqrt{G \eta \eta}}{\sqrt{G \zeta \zeta} \sqrt{G \eta \eta}}+\frac{u v \sqrt{G \zeta \zeta}}{\sqrt{G \zeta \zeta} \sqrt{G \eta \eta}}-F v \\
=\frac{u v \sqrt{G \zeta \zeta}}{\sqrt{G \zeta \zeta} \sqrt{G \eta \eta}}-F v=\frac{1}{(d+\zeta)^{2}} v \frac{\partial u}{\partial \sigma}+M \zeta \\
\frac{\partial \zeta}{\partial r}+\frac{u \partial u}{\sqrt{G \zeta \zeta} \partial \zeta}+\frac{v \partial u}{\partial \eta \sqrt{G \eta}}+\frac{\omega \partial u}{d+\zeta \partial \sigma}-\frac{\omega \partial u}{d+\zeta \partial \sigma} \\
-\frac{u v \sqrt{G \eta \eta}}{\sqrt{G \zeta \zeta} \sqrt{G \eta \eta}}+\frac{V^{2} \sqrt{G \zeta \zeta}}{\sqrt{G \zeta \zeta} \sqrt{G \eta \eta}}-F v \\
=\frac{1}{\rho 0 \sqrt{G \zeta \zeta}} P \zeta+F \zeta+\frac{1}{(d+\zeta)^{2}} v \frac{\partial u}{\partial \sigma}+M \zeta
\end{gathered}
$$

Persamaan Kontinuitas

$$
\begin{aligned}
& \frac{\partial \zeta}{\partial r}+\frac{1 \partial[(d+\zeta) U \sqrt{G \eta \eta}]}{\sqrt{G \zeta \zeta} \sqrt{G \eta \eta} \partial \zeta}+\frac{1 \partial[(d+\zeta) V \sqrt{G \zeta \zeta}]}{\sqrt{G \zeta \zeta} \sqrt{G \eta \eta} \partial \eta} \\
& =(d+\zeta) Q
\end{aligned}
$$

Keterangan:

$\sqrt{\mathrm{G} \zeta \zeta=}=$ koefisien transformasi kurvalimier menjadikoordinat persegi $(\mathrm{m})$,

$\sqrt{\mathrm{G} \eta \eta=}=$ koefisien transformasi kurvalimier menjadi koordinat persegi (m),

$\mathrm{G}=$ percepatan gravitasi $\left(\mathrm{m} / \mathrm{s}^{2}\right)$,

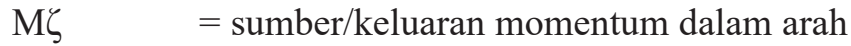
$\mathrm{x} / \zeta(\mathrm{kg} \mathrm{m} / \mathrm{s})$

$\mathrm{M \eta}=$ sumber/keluaran momentum dalam arah $\mathrm{y} / \mathrm{\eta}(\mathrm{kg} \mathrm{m} / \mathrm{s})$,

$\mathrm{U}=$ kecepatan rata-rata terhadap kedalaman pada $\operatorname{arah} \mathrm{x} / \zeta(\mathrm{m} / \mathrm{s})$,

= kecepatan aliran dalam tanah $\mathrm{x} / \zeta(\mathrm{m} / \mathrm{s})$,

= kecepatan rata-rata terhadap kedalaman pada arah $\mathrm{y} / \eta(\mathrm{m} / \mathrm{s})$,

$=$ kecepatan aliran dalam tanah $\mathrm{y} / \eta(\mathrm{m} / \mathrm{s})$,

$=$ frekuensi sudut pasang surut dan atau

komponen Fourier,

= elevasi muka air (m).

Persamaan Spektrum Gelombang

$$
\begin{aligned}
& \frac{\partial}{\partial t} N+\frac{\partial}{\partial x} c x N+\frac{\partial}{\partial y} c y N+\frac{\partial}{\partial \sigma} c \sigma N \\
& +\frac{\partial}{\partial \theta} c \theta N=\frac{S}{\sigma}
\end{aligned}
$$

Analisis dan desain hidraulik perbaikan muara sungai Analisis dan desain hidraulik untuk perbaikan muara 
sungai pada studi ini berdasarkan pedoman umum perbaikan muara sungai dengan jetty yang diterbitkan oleh Panitia Teknik Konstruksi dan Bangunan, Departemen Permukiman dan Prasarana Wilayah, KemenPUPR, pada tahun 2004.

Perhitungan yang dilakukan yaitu perhitungan kedalaman minimum alur pelayaran dan lebar minimum alur pelayaran. Perhitungan kedalaman alur pelayaran dilakukan dengan menggunakan data kapal yang berasal dari penelitian sebelumnya yang dilakukan oleh Jayanti \& Wiyono (2009), yaitu kapal motor dengan panjang kapal berkisar 9-10 meter, lebar kapal 1-1,8 meter, draft kapal antara 0,5-0,8 meter,dan lebar katir $\pm 1,5$ meter. Pada penelitian ini lebar kapal diasumsikan sebesar 4,8 m. Pers. (5) adalah persamaan yang digunakan untuk menentukan kedalaman alur pelayaran, sedangkan Pers. (6) adalah persamaan yang digunakan untuk menghitung lebar minimum alur pelayaran.

ELbed $=$ LLWL $-\mathrm{dn}$

$\mathrm{dn}=\mathrm{df}+\mathrm{gl}+\mathrm{rb}$

ELbed adalah elevasi dasar alur (pada kedalaman minimum) (m); LLWL adalah elevasi muka air pada surut terendah $( \pm 0,00)(\mathrm{m})$; dn adalah kedalaman alur nominal (m); df adalah draft kapal pada muatan penuh (m), gl adalah gerakan kapal akibat gelombang $(\mathrm{m})$; rb adalah ruang bebas di bawah kapal (m). gl+rb bisa diambil $=50 \% \mathrm{df}$.

Untuk lalu lintas satu jalur

$\mathrm{Wn}>4,8 \mathrm{~B}$

Untuk lalu lintas dua jalur

$\mathrm{Wn}>7,6 \mathrm{~B}$

Wn adalah lebar alur minimum (m); B adalah lebar kapal yang berukuran terbesar $(\mathrm{m})$.

\section{Perencanaan Jetty}

Perencanaan jetty pada studi ini mengacu pada pedoman perencanaan jetty tipe rubble mound untuk penanggulangan penutupan muara sungai oleh sedimen yang diterbitkan oleh Panitia Teknik Konstruksi dan Bangunan Sipil, Departemen Pekerjaan Umum, KemenPUPR pada tahun 2005.

\section{Model Setup}

Grid yang digunakan pada pemodelan Delft3D yaitu curvilinier grid dengan ukuran panjang grid \pm 2.250 meter dengan lebar \pm 1.560 meter di bagian utara dan \pm 1.980 meter di bagian selatan dengan interval grid yaitu \pm 30 meter (Gambar 2). Pemodelan dilakukan untuk kondisi tanpa jetty eksisting yang ada saat ini. Hal ini disebabkan karena ukuran grid model yang lebih besar dari ukuran lebar jetty eksisting. Pada model ini muara Sungai Cilauteureun yang ke arah selatan tidak diperhitungkan. Debit sungai diinput pada grid yang berada di mulut sungai dekat jetty eksisting dengan nilai konstan, sedangkan sedimen diasumsikan hanya berasal dari laut saja.

Simulasi pemodelan hidrodinamika dan transformasi gelombang dilakukan untuk dua buah skenario, yaitu pada saat musim barat dan pada saat musim timur. Durasi simulasi pemodelan pada musim barat dan musim timur masing-masing hanya selama 1 bulan, yaitu pada Januari untuk mewakili kondisi musim barat dan bulan Agustus untuk mewakili kondisi musim timur. Selanjutnya pemodelan transpor sedimen dilakukan dengan durasi pemodelan selama 1 tahun yaitu pada 1 Januari 2018 sampai dengan 31 desember 2018 dengan menggunakan data angin dominan selama 1 tahun.

\section{Data Input pada Pemodelan \\ Batimetri}

Data batimetri yang digunakan pada penelitian ini

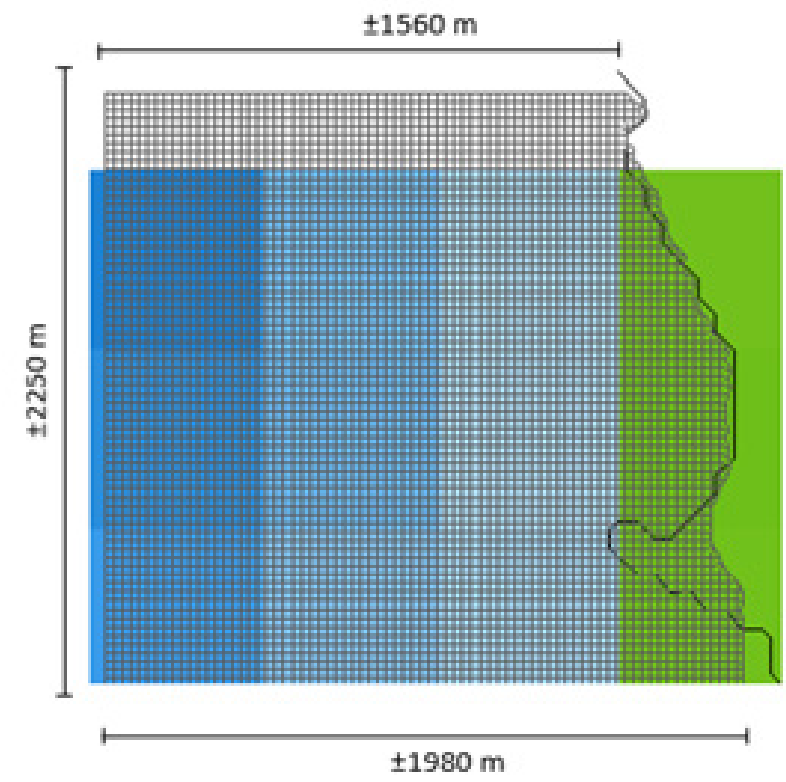

Gambar 2. Domain Model.

Figure 2. Domain Model..

Sumber: Hasil penelitian 
diperoleh dari Gebco dalam DELFT Dashboard yang memiliki resolusi sebesar 15 arc second atau setara dengan $450 \mathrm{~m}$. Data ini kemudian di re-gridding sehingga resolusinya menjadi $30 \mathrm{~m}$.

\section{Pasang surut}

Data pasang surut diperoleh dari DELFT Dashboard yaitu berupa data komponen pasang surut M2, S2, N2, K2, K1, O1, P1, Q1, Mf, Mm, M4, Ms4, dan Mn4 yang kemudian dimasukan sebagai syarat batas pemodelan pada boundary model di bagian utara, barat dan selatan (Mustikasari et al., 2015).

\section{Kecepatan dan Arah Angin}

Data angin diperoleh dari ECMFW (European Centre for Medium-Range Weather Forecasts). Data angin yang digunakan pada pemodelan yaitu arah dan kecepatan angin dominan pada musim barat dan musim timur (Muliati et al., 2019), dan juga arah dan kecepatan angin dominan selama satu tahun (1 Januari - 31 desember 2018). Arah angin dominan pada musim barat yaitu dari arah barat daya dan kecepatan $5,85 \mathrm{~m} / \mathrm{s}$, sedangkan angin dominan saat musim timur bertiup dari arah barat dengan kecepatan 2,90 m/s.

\section{Tinggi Gelombang}

Hindcasting gelombang dengan menggunakan data angin dilakukan untuk mendapatkan nilai tinggi gelombang signifikan dan periode gelombang. Tinggi gelombang periode ulang untuk $2,5,10,15,25$, dan 50 tahun dihitung dengan menggunakan metode log normal. Selanjutnya tinggi gelombang periode ulang 50 tahun dijadikan sebagai input nilai awal tinggi dan periode gelombang pada pemodelan dengan Delft3DWave, yaitu sebesar 1,32 m dengan periode 4,72 detik.

\section{Data Debit Sungai}

Data debit sungai yang digunakan berdasarkan data observasi pada penelitian yang dilakukan oleh Pratomo, et al. (2017). Pengukuran debit sungai dilakukan pada 2 buah stasiun yang berada di aliran Sungai Cilauteureun. Pada penelitian ini nilai debit sungai pada kedua stasiun selama waktu observasi dirata-ratakan kemudian dijadikan sebagai input pada pemodelan hidrodinamika. Nilai debit sungai yang diinput pada model yaitu sebesar 19,93 $\mathrm{m}^{3} /$ detik. Besarnya debit sungai yang digunakan pada pemodelan diasumsikan seragam untuk musim barat maupun musim timur.

\section{Data Sedimen}

Data sedimen yang digunakan yaitu data observasi pada penelitian yang juga dilakukan oleh Pratomo, et al (2017). Pengukuran laju sedimentasi di tujuh stasiun di sekitar muara Sungai Cilauteureun dan mulut jetty eksisting. Pada penelitian ini nilai laju sedimentasi pada ke-tujuh stasiun selama waktu observasi dirata-ratakan kemudian dijadikan sebagai input pada pemodelan transpor sedimen. Nilai konsentrasi sedimen dihitung berdasarkan nilai laju sedimentasi rata-rata $0,4648 \mathrm{~kg}$ / $\mathrm{m} 3 / \mathrm{jam}$. Besarnya konsentrasi yang digunakan pada pemodelan diasumsikan seragam untuk musim barat maupun musim timur (Diputra et al., 2018).

\section{HASIL DAN PEMBAHASAN}

\section{Hasil Pemodelan Hidrodinamika dan Transpor Sedimen}

Hasil simulasi pemodelan dengan menggunakan Delft3D-Flow terlebih dahulu diverifikasi dengan menggunakan data observasi tide gauge (Muliati et al., 2016), dari Badan Informasi Geospasial (BIG), selama 15 hari yaitu 1 Agustus 2018 sampai 15 Agustus 2018. Gambar 3 menunjukan grafik perbandingan elevasi muka air laut hasil model dengan data dari BIG.

Pada grafik terlihat adanya perbedaan ketinggian muka air hasil model dengan data dari BIG yaitu sekitar 10 sampai $30 \mathrm{~cm}$ pada beberapa waktu. Namun dari hasil perbandingan tersebut dapat dikatakan hasil model sudah sesuai dengan kondisi lapangan dan model tervalidasi dengan cukup baik.

Kecepatan dan arah arus hasil pemodelan dengan Delft3D Flow pada saat kondisi musim barat yang diwakili oleh bulan Januari (Siregar et al., 2017), dapat dilihat pada Gambar 4 (a). Sedangkan kecepatan dan arah arus saat kondisi musim timur yang diwakili oleh bulan Agustus (Siregar et al., 2017), dapat dilihat pada Gambar 4 (b). Pada gambar 4 terlihat kecepatan arus di area Pantai Santolo relatif rendah.

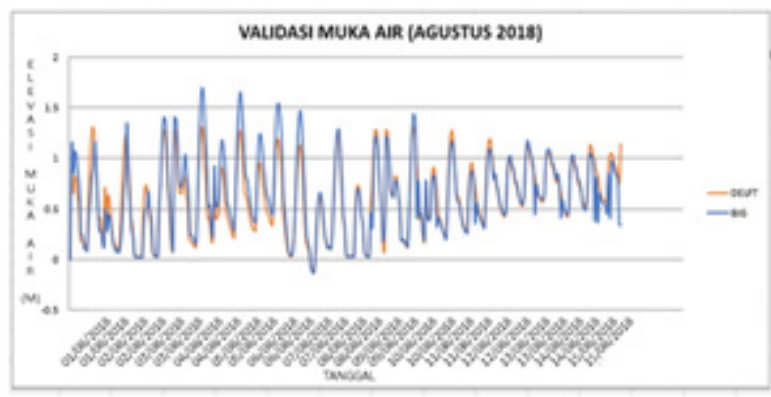

Gambar 3. Perbandingan Elevasi Muka Air Hasil Pemodelan dengan Data BIG.

Figure 3. Comparison of Water Level of Model Results with Data from BIG.

Sumber: Hasil penelitian 

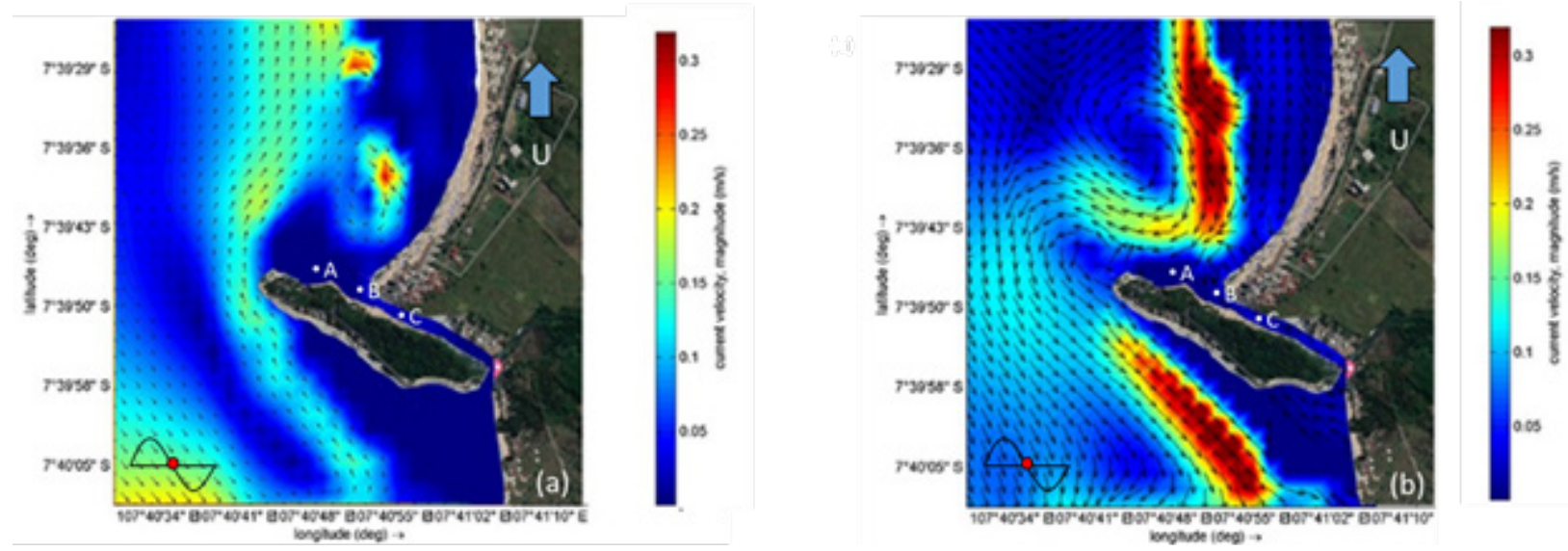

Gambar 4. Kecepatan arus (m/s) pada saat pasang purnama kondisi menuju surut saat (a) musim timur dan (b) musim barat

Figure 4. Current velocity at spring tide and when ebb condition during (a) east monsoon and (b) west monsoon. Sumber: Hasil penelitian

Analisis perbandingan kecepatan arus ditinjau pada tiga buah titik, yaitu titik A, titik B, dan titik C. Ketiga titik tersebut berada di jalur lalu lintas pelayaran kapal nelayan di sekitar mulut muara Sungai Cilauteureun. Perbandingan nilai kecepatan arus selama waktu simulasi dapat dilihat pada grafik pada Gambar 5 . Nilai kecepatan arus di ekstrak pada titik A, B, dan C baik pada musim timur maupun musim barat.

Kecepatan arus rata-rata saat musim barat pada titik A yaitu $0,125 \mathrm{~m} / \mathrm{s}$, sedangkan pada titik B yaitu 0,75 $\mathrm{m} / \mathrm{s}$, dan pada titik C yaitu $0,0035 \mathrm{~m} / \mathrm{s}$. Sementara kecepatan arus rata-rata saat musim timur pada titik A yaitu $0,045 \mathrm{~m} / \mathrm{s}$, sedangkan pada titik B yaitu 0,0135 $\mathrm{m} / \mathrm{s}$, dan pada titik C yaitu $0,0045 \mathrm{~m} / \mathrm{s}$. Sementara Kecepatan arus saat musim barat relatif lebih besar dibandingkan saat musim timur. Kecepatan arus saat musim barat di sekitar muara Sungai Cilauteureun terutama di bagian mulutnya lebih besar dibandingkan saat musim timur, seperti yang terlihat pada Gambar 4 dan. Namun, besarnya kecepatan arus ini relatif kecil sehingga memungkinkan sedimen di lokasi tersebut terendapkan dan menyebabkan terbentuknya tombolo di sekitar bagian ujung jetty.

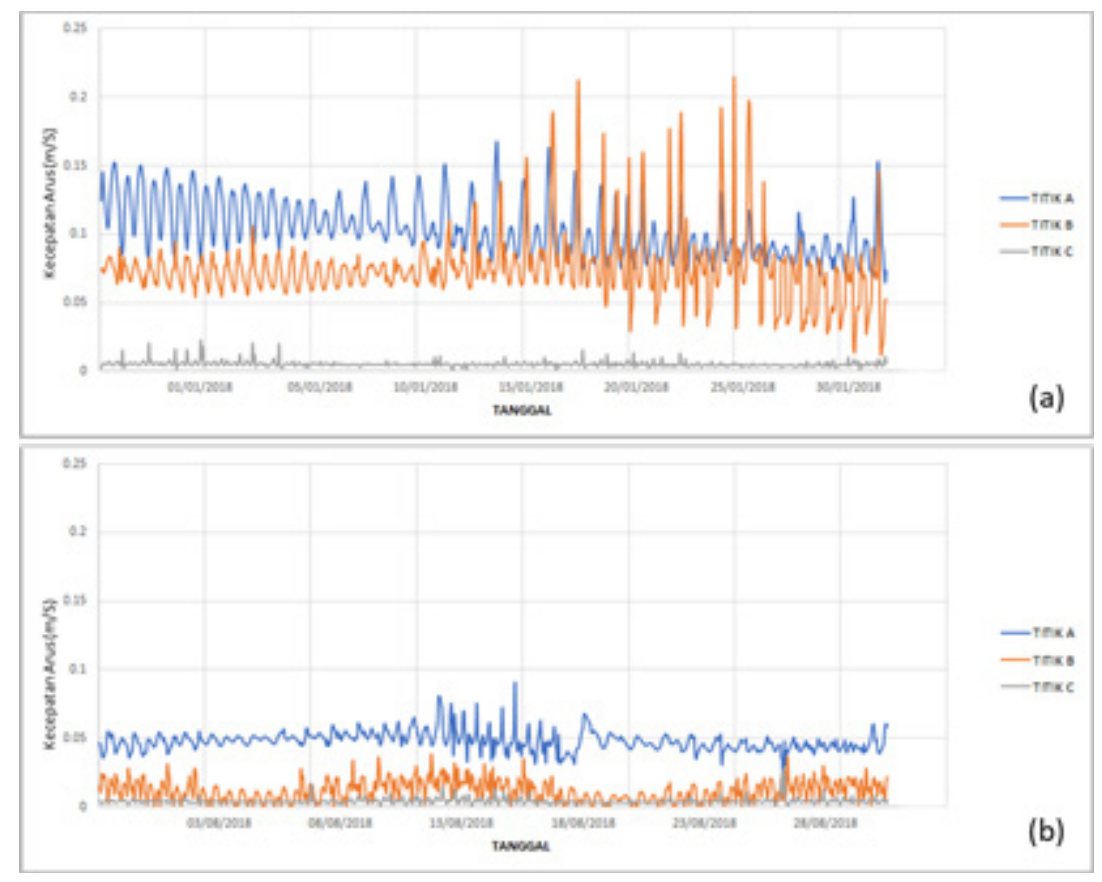

Gambar 5. Perbandingan kecepatan arus di titik A, B, dan C saat (a) musim barat dan saat (b) musim timur. Figure 5. Comparison of current velocity at A,B, and C point during (a) west monsoon and (b) east monsoon. Sumber: Hasil penelitian ini 
Hasil pemodelan transformasi gelombang ditunjukan oleh Gambar 6. Pada Gambar 6 terlihat adanya refraksi gelombang baik pada musim barat maupun musim timur di bagian depan mulut muara sungai Cilauteureun. Gelombang dari laut dalam yang datang dari arah barat daya pada musim barat, dan dari arah barat pada musim timur mengalami refraksi sehingga di area depan mulut sungai gelombang datang dari barat laut. Gelombang ini membawa sedimen dari laut dan kemudian terendapkan di area tersebut. Grafik perbandingan besarnya tinggi gelombang pada titik A, $\mathrm{B}$, dan $\mathrm{C}$ dapat dilihat pada Gambar 7.

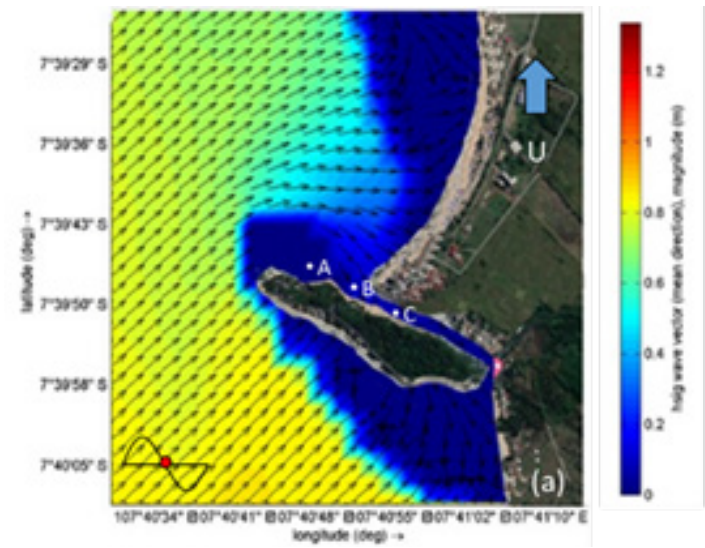

Tinggi gelombang signifikan rata-rata saat musim barat pada titik A yaitu $1,218 \mathrm{~m}$, sedangkan pada titik B yaitu $0,437 \mathrm{~m}$, dan pada titik $\mathrm{C}$ yaitu $0,260 \mathrm{~m}$. Sementara tinggi gelombang signifikan rata-rata saat musim timur pada titik A yaitu $0,507 \mathrm{~m}$, sedangkan pada titik B yaitu $0,220 \mathrm{~m}$, dan pada titik $\mathrm{C}$ yaitu $0,097 \mathrm{~m}$. Tinggi gelombang signifikan saat musim barat cenderung lebih tinggi dibandingkan saat musim timur.Hal ini sesuai dengan pernyataan Jayanti \& Wiyono (2009) dimana sebagian besar nelayan tidak melaut pada musim barat. Nelayan lebih banyak melaut pada musim timur karena kondisi perairan yang relatif lebih tenang.

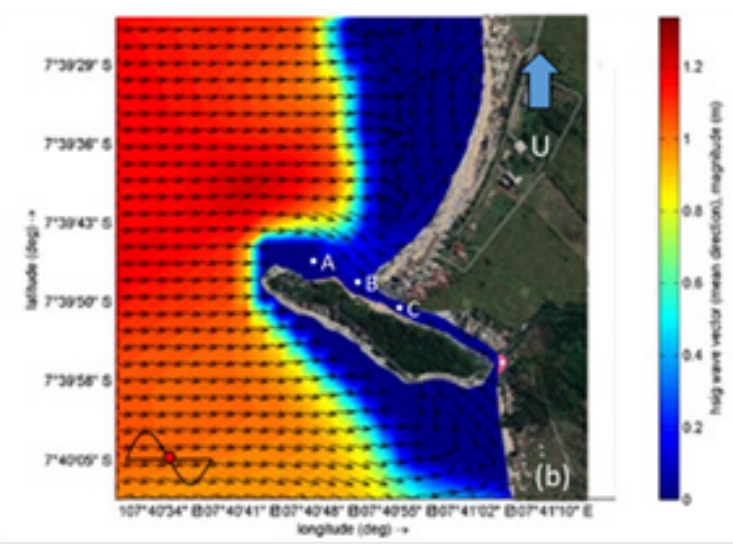

Gambar 6. Perbandingan kecepatan arus di titik A, B, dan C saat (a) musim barat dan saat (b) musim timur. Figure 6. Comparison of current velocity at A,B, and C point during (a) west monsoon and (b) east monsoon. Sumber: Hasil penelitian ini

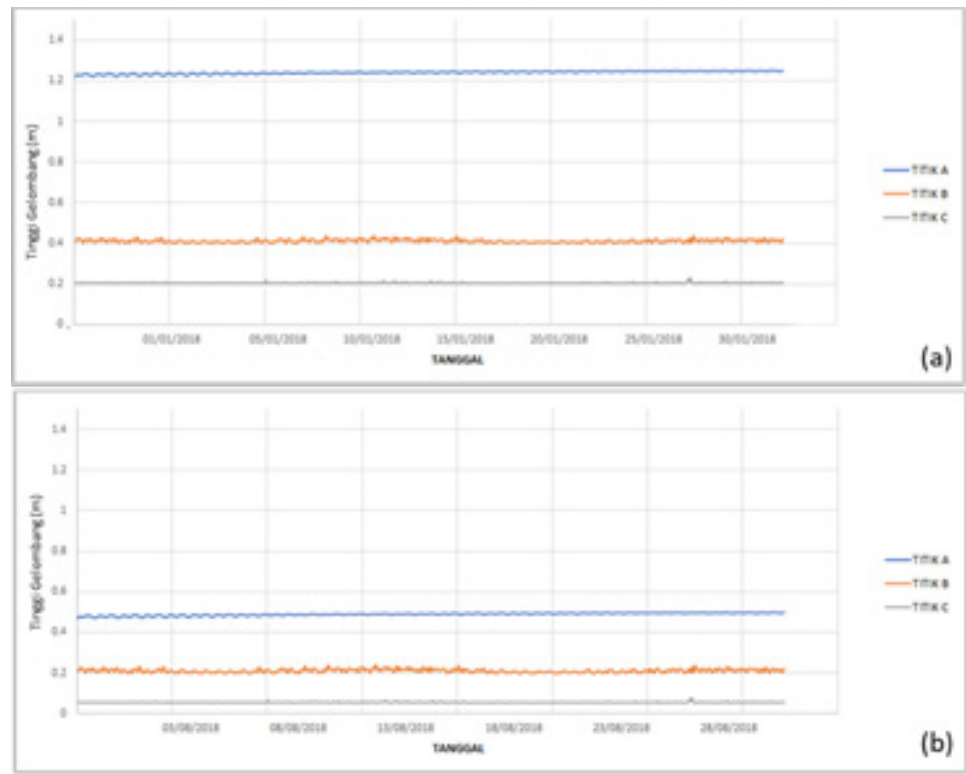

Gambar 7. Perbandingan tinggi gelombang signifikan (m) di titik A, B, dan C saat (a) musim barat dan saat (b) musim timur.

Figure 7. Comparison of current velocity at A,B, and C point during (a) west monsoon and (b) east monsoon. Sumber: Hasil penelitian ini 
Selain simulasi arus dan tinggi gelombang, penelitian ini juga mensimulasikan kondisi sedimentasi dan erosi yang terjadi di sekitar area Pantai Santolo. Besarnya kumulatif sedimentasi dan erosi dapat dilihat pada Gambar 8. Nilai negatif menunjukan terjadinya erosi, sedangkan nilai positif menunjukan terjadinya sedimentasi. Berdasarkan hasil simulasi selama satu tahun, terlihat di area Pantai Santolo terjadi sedimentasi termasuk di muara Sungai Cilauteureun sebesar $1 \mathrm{~m}$.

\section{Penanggulangan permasalahan sedimentasi dan perencanaan jetty}

Rekomendasi untuk penanggulangan permasalahan sedimentasi pada penelitian ini dibuat berdasarkan hasil pemodelan hidrodnamika dan transpor sedimen yang telah dilakukan sebelumnya. Solusi yang direkomendasikan untuk mengatasi permasalahan tersebut yaitu dibangun jetty didekat jetty eksisting/ dermaga peninggalanan Belanda (Rachman et al., 2013). Sand by passing juga dilakukan pada tombolo yang terbentuk di belakang jetty yang telah dibangun sebelumnya ke pantai yang terlihat mengalami erosi. Pada penelitian ini, tipe jetty yang direncanakan yaitu jetty tipe rubble mound.

Berdasarkan hasil perhitungan yang dilakukan didapatkan kedalaman minimum alur yang dibutuhkan untuk kapal dengan draft sebesar $0,8 \mathrm{~m}$ di muara Sungai Cilauteureun yaitu minimal 1,249 $\mathrm{m}$ di bawah LLWL. Sedangkan lebar alur pelayaran di mulut jetty untuk lebar kapal sebesar 4,8m dan untuk lalu lintas 2 jalur yaitu minimal sebesar $37 \mathrm{~m}$.

Pada penelitian ini, pangkal jetty direncanakan ditempatkan pada ujung jetty eksisting/dermaga peninggalan Belanda yang terletak di bagian ujung barat Pulau Santolo. Untuk meredam gelombang refraksi dari arah barat laut maka ujung jetty ditempatkan pada arah $67^{\circ}$ dengan jarak $120 \mathrm{~m}$ dari pangkal jetty, sehingga terdapat celah antara ujung jetty yang direncanakan dengan sisa potongan jetty eksisting sebesar 60 meter

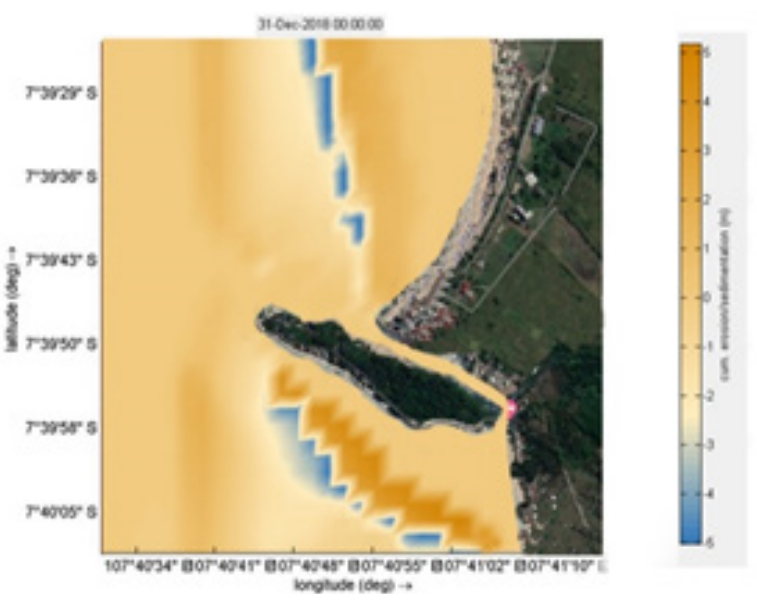

Gambar 8. Kumulatif erosi/sedimentasi pada area pemodelan selama 1 tahun simulasi.

Figure 8. Cumulative erosion/sedimentation in modeling area for 1 year simulation.

Sumber: Hasil penelitian ini

untuk alur lalu lintas kapal. Besarnya lebar celah ini telah sesuai dengan perhitungan minimum lebar alur untuk lalu lintas 2 jalur kapal yang telah dilakukan sebelumnya $(37 \mathrm{~m})$. Elevasi mercu pada bagian pangkal jetty yaitu sebesar 2,3584 m, sedangkan pada bagian ujung/kepala jetty yaitu sebesar $2,8584 \mathrm{~m}$.

Perhitungan dimensi armor dan lapisan pengisi dilakukan untuk 2 buah bagian, yaitu bagian I yang merupakan struktur bagian kepala, dan bagian II yang merupakan struktur bagian badan. Tinggi gelombang di sekitar struktur didapatkan dari hasil pemodelan gelombang, dimana pada perhitungan ini besarnya tinggi gelombang di dekat struktur yang digunakan adalah sebesar $1,36 \mathrm{~m}$ di bagian badan dan $1,75 \mathrm{~m}$ di bagian kepala. Armor yang digunakan batu belah bulat kasar (batu pecah). Perhitungan berat butir batu (W), diameter batu (D), lebar mercu (B). Hasil perhitungan dimensi armor dan lapisan pengisi untuk bagian I dan bagian II dapat dilihat pada Tabel 1 dan Tabel 2.

Tinggi suatu bangunan harus memperhitungkan besarnya tinggi rayapan/run up $(\mathrm{Ru})$ pada bangunan

Tabel 1. Dimensi armor dan lapisan pengisi struktur bagian kepala (bagian I) Table 1.Dimensions of the armor and filler layer of the head structure (part I)

\begin{tabular}{llllllll}
\hline Hd (m) & $\mathbf{W}(\mathbf{k g})$ & $\mathbf{D}(\mathbf{m})$ & $\begin{array}{l}\text { Lebar } \\
\text { Mercu } \\
(\mathbf{m})\end{array}$ & $\begin{array}{l}\text { Wapis } \\
\text { kedua } \\
(\mathbf{k g})\end{array}$ & $\begin{array}{l}\text { D(m) } \\
\text { Lengisan }\end{array}$ & $\begin{array}{l}\text { W } \\
\text { Lapisan } \\
\text { Pengisi }\end{array}$ \\
\hline 1,75 & 1300 & 0,8 & 3 & 130 & 0,6 & 6,5 & $10-20$ \\
\hline
\end{tabular}


Tabel 2. Dimensi armor dan lapisan pengisi struktur bagian badan (bagian II)

Table 2.Dimensions of the armor and filler layers of the trunk structure (part II)

\begin{tabular}{llll}
\hline Hd & W & D & B \\
\hline $1,36 \mathrm{~m}$ & $600 \mathrm{Kg}$ & $0,6 \mathrm{~m}$ & $3 \mathrm{~m}$ \\
\hline
\end{tabular}

Sumber : Hasil penelitian

yang dihitung dengan menggunakan fungsi bilangan irribaren. Sedangkan gerusan lokal pada perencanaan jetty ini diasumsikan hanya gerusan yang diakibatkan oleh hempasan gelombang. Koefisien gerusan yang digunakan yaitu sebesar 0,5. Tinggi struktur total dihitung berdasarkan cadangan penurunan struktur, tinggi rayapan, beda pasang surut, kedalaman air saat LLWL, dan gerusan lokal. Cadangan untuk kemungkinan penurunan struktur diasumsikan 0,5 $\mathrm{m}$. Hasil perhitungan tinggi runup dan gerusan lokal masing-masing sebesar $1,93 \mathrm{~m}$ dan $0,35 \mathrm{~m}$. Maka total tinggi struktur jetty yaitu sebesar 5,96 m, sedangkan tinggi struktur berdasarkan kedalam alur yaitu sebesar 4,99 m. Layout penempatan jetty dan penampang melintang jetty bagian kepala ditunjukan oleh gambar 10 dan Gambar 10.

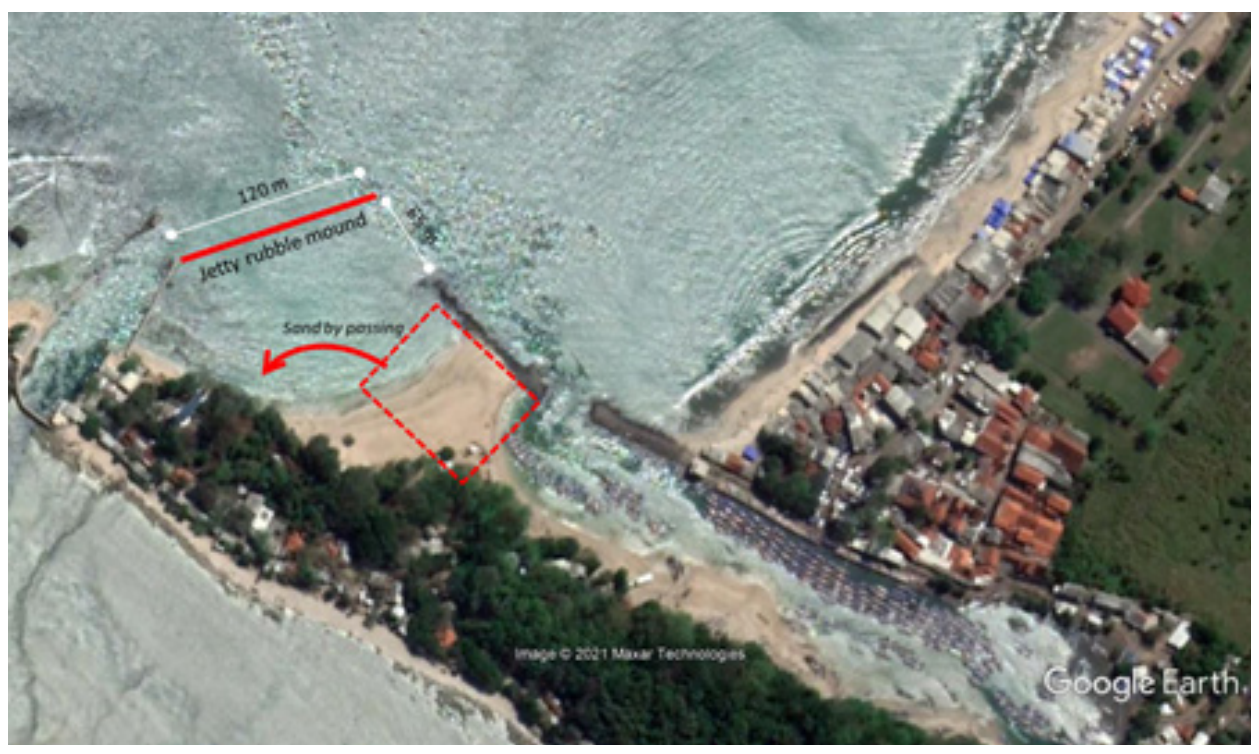

Gambar 9. Layout penempatan jetty dan sand by passing.

Figure 9. Jetty and sand by passing placement layout. Sumber : Hasil penelitian

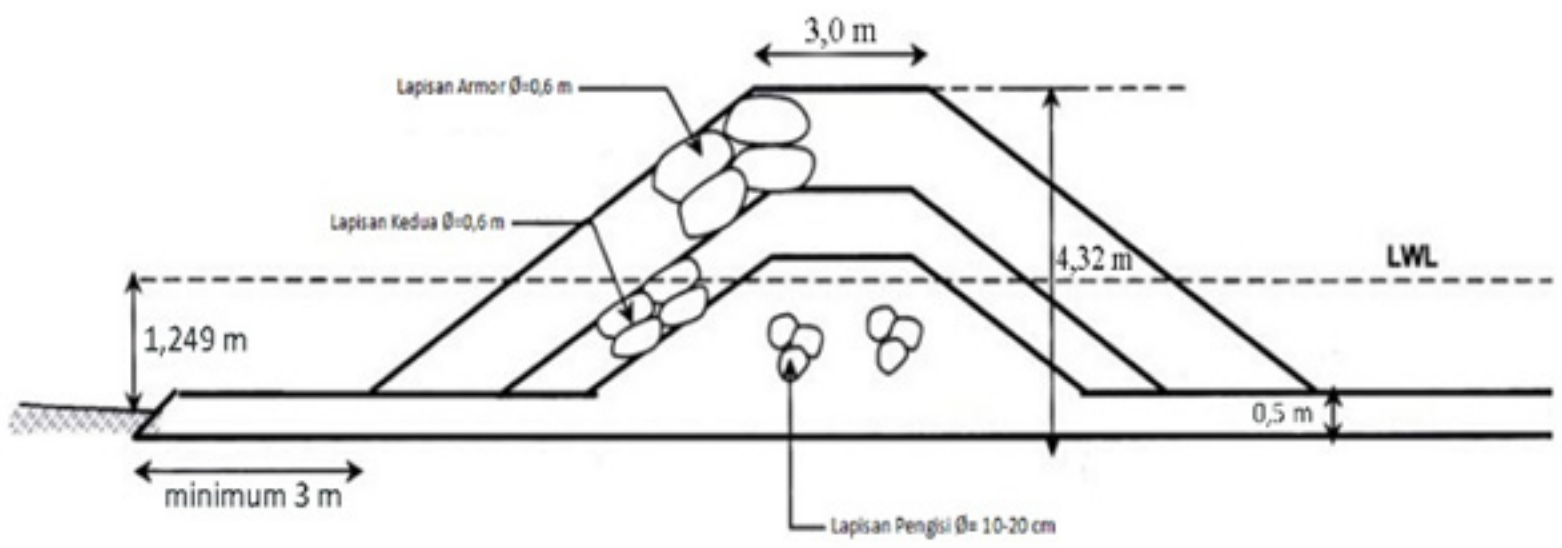

Gambar 10. Penampang melintang jetty rekomendasi bagian kepala.

Figure 10. Cross section head jetty.

Sumber : Hasil penelitian 


\section{KESIMPULAN DAN SARAN}

Berdasarkan analisis hasil pemodelan dan perhitungan perencanaan jetty yang telah dilakukan maka pada penelitian ini dapat disimpulkan:

- Refraksi gelombang dengan tinggi gelombang yang mencapai $\pm 1,2 \mathrm{~m}$ pada musim barat dan $\pm 0,5$ $\mathrm{m}$ pada musim timur yang terjadi di Pantai Santolo dan mulut muara Sungai Cilauteureun membawa sedimen dari laut dan kemudian sedimen tersebut terendapkan di area tersebut

- karena kecepatan arus yang relatif rendah yaitu sekitar $0-0,2 \mathrm{~m} / \mathrm{s}$ baik pada musim barat maupun musim timur.

- Rekomendasi penanggulangan terhadap permasalahan penumpukan sedimen di mulut muara sungai yang ada saat ini yaitu dengan menggunakan bangunan pelindung pantai berupa jetty tipe rubble mound sepanjang $120 \mathrm{~m}$ dengan ujung jetty menghadap sudut 670 yang ditempatkan pada ujung jetty eksisting peninggalan Belanda yang berada di bagian ujung barat Pulau Santolo. Sand by passing juga dilakukan pada tombolo yang saat ini terdapat di belakang jetty eksisting yang terpotong.

- Jetty direncanakan dibangun tegak lurus pantai, dengan berat butir batu pelindung bagian kepala $1300 \mathrm{Kg}$, berat butir batu pelindung bagian badan $600 \mathrm{Kg}$, lebar mercu $3 \mathrm{~m}$, diameter batu pelindung bagian kepala $0,8 \mathrm{~m}$, diameter batu pelindung bagian badan $0,6 \mathrm{~m}$, tinggi struktur total $5,96 \mathrm{~m}$.

\section{UCAPAN TERIMA KASIH}

Ucapan terima kasih diberikan kepada semua pihak yang telah membantu terlaksananya seluruh kegiatan penelitian sampai selesai.

\section{DAFTAR PUSTAKA}

Badan Pusat Statistik Kabupaten Garut. Produksi dan Nilai Produksi Perikanan di Kabupaten Garut tahun 2015-2017. https://garutkab.bps.go.id [Diakses 26 Desember 2020]

Badan Informasi Geospasial. Real Time Tidal Observation Stasiun Pameungpeuk. tides.big. go.id [Diakses 1 Agustus 2020]

Deltares. (2014). Delft3D-Flow, Simulation of multidimensional hydrodynamic flows and transport phenomena, including sediments, User Manual, Version 3.15.34158, May 2014, 684 pp

Diputra, A. E., Simanjuntak, S.M., Pranowo, W. S. \& Adrianto, D. (2018). Studi Hidrodinamika dan Pola Sebaran Sedimen pada Perencanaan Pembangunan Dermaga Pangkalan TNI AL di Teluk Ratai - Lampung. J. Chart Datum, 4(2), 75-86.

Fahmi, M., \& Hafli, T. M. (2019). Simulasi Numerik Perubahan Morfologi Pantai Akibat Konstruksi Jetty pada Muara Lambada Lhok Aceh Besar Menggunakan Software Delft3D. Jurnal Teknik Sipil Universitas Syiah Kuala 8(2), 50-59.

Jayanti, P. D., \& Wiyono, E. S. (2009). Pola Usaha Perikanan Tangkap di PPP Cilauteureun Kabupaten Garut, Jawa Barat. Skripsi Departemen Pemanfaatan Sumberdaya Perikanan. IPB (Bogor Agricultural Technology).

Muliati, Y., Tawekal, R. L., Wurjanto, A., Kelvin, J., \& Pranowo. W. S. (2019). Wind Wave Modeling in Natuna Sea: A Comparison Among SWAN, SEAFINE, and ERA-INTERIM. International Journal of GEOMATE, 16(54), 176-184.

Muliati, Y., Wurjanto, A., \& Pranowo, W. S. (2016). Validation of Altimeter Significant Wave Height Using Wave Gauge Measurement in Pacitan Coastal Waters, East Java, Indonesia. International Journal of Advances in Engineering Research, 12(4), 25-33.

Mustikasari, E., Dewi, L. C., Heriati, A., \& Pranowo, W. S. (2015). Pemodelan Pola Arus Barotropik Musiman 3 Dimensi(3D) Untuk Mensimulasikan Fenomena Upwelling di Perairan Indonesia. $J$. Segara,11(1), 25-35.

Pratomo, F. K., Hariadi, H., \& Widada, S. (2017). Analisa Laju Sedimentasi Di Muara Sungai Cilauteureun Garut. Journal of Oceanography, 6(1), 54-60.

Prihantono, J., Fajrianto, I. A., \& Kurniadi. Y. N. (2018). Pemodelan Hidrodinamika Dan Transpor Sedimen di Perairan Pesisir Sekitar Tanjung Pontang, Kabupaten Serang - Banten. $J$. Kelautan Nasional, 13(2), 75-88.

Purbani, D., Salim, H. L., Kusuma, L. P. A. S. C. 
Tussadiah, A., Subandriyo. J. (2019). Ancaman Gelombang Ekstrim dan Abrasi pada Penggunaan Lahan di Pesisir Kepulauan Karimunjawa (Studi Kasus: Pulau Kemujan, Pulau Karimunjawa, Pulau Menjangan Besar dan Pulau Menjangan Kecil). J. Kelautan Nasional, 14(1), 33-45.

Rachman, M. M., Armono, H. D. \& K. Sambodho. (2013). Komparasi Metode Daya Dukung Axial Pada Tiang Pancang Tunggal (Studi Kasus Jetty Barge Loading Conveyor, Meulaboh). $J$. Kelautan Nasional, 8(2), 73-80.

Siregar, S. N., Sari, L. P. Purba, N. P., Pranowo, W. S.,. \& Syamsuddin, M. L. (2017). Pertukaran massa air di Laut Jawa terhadap periodisitas monsun dan Arlindo pada tahun 2015. J. Depik, 6(1), 4459.

Soedjana, K. (2002). Kajian Penanganan Masalah Sedimentasi Di Muara Sungai Cilauteureun, Kecamatan Cikelet Kabupaten Garut. Tesis Magister Program Studi Teknik Sipil. Institut Teknologi Bandung.

Syamsudin., Yuwono, N. , Hoedijatmoko, \& Riandini, F. (2004). Perbaikan Muara Sungai Dengan Jetty. Pedoman Konstruksi dan Bangunan. Badan Litbang PU Departemen Permukiman dan Prasarana Wilayah.

Syamsudin, Yuwono, N. \& Azhar, R. M. (2005). Pedoman Perencanaan Jetty Tipe Rubble Mound Untuk Penanggulangan Penutupan Muara Sungai oleh Sedimen. Pedoman Konstruksi dan Bangunan. Badan Litbang PU Departemen Pekerjaan Umum, Jakarta. 
